\title{
Controversial of Transformation Online Mode Transportation in Pekalongan City, Indonesia
}

\author{
Nilam Adini R. ${ }^{1}$, Hardi Warsono ${ }^{2}$ \\ \{nilamadini.r@gmail.com ${ }^{1}$,warsono_hardi@live.undip.ac.id²\} \\ Universitas Diponegoro, Indonesia ${ }^{1,2}$
}

\begin{abstract}
Concerning on the appearance of the present technology accompanied by the use of internet which increase rapidly, triggering a demand for economic needs one of the examples is in the field of transportation. Transportation is a type of treatment in the service sector. The existence of public transportation services provided by the government that has not optimally made the interest of using public, transportation is decreased. On the other hand, this opportunity is seen by the private sector which provides application-based transportation that can be accessed anytime, anywhere. The change of the public transportation's model to online application-based transportation is very attractive to the public is a form of social change in society that requires convenience in addition to the controversy that occurs in the use of transportation modes. This research is the descriptive research method through library research. The kind of data that is used is secondary data. The Data collection techniques in this research are carried out through the review of books, literature, notes and various reports relating to the problem to be solved. The conclusion of this research is that there are four factors driving unplanned change that underlie the controversial transformation of online transportation modes, they are (1) shifting workers' demographics, (2) performance gaps, (3) government regulations, and (4) advancements in technology. The people's preference for choosing online modes of transportation rather than public transportation must be immediately anticipated by the government to avoid potential conflicts in the future.
\end{abstract}

Keywords: Transformation; Controversy; Public Transportation; Online Transportation.

\section{Introduction}

Along with the development of the times in this era of globalization, rapid technological development increasingly demanding public to follow the developments. Moreover, these developments also provide convenience to the people in everyday life, so that people now have the option to use practical things, one of them through the internet. According to the Asosiasi Penyedia Jasa Internet Indonesia (APJII) [1] the population of Indonesia is currently at 171.17 million . Internet users in Indonesia reached 64.8 percent, or about 246.16 million people have been connected to the Internet network throughout 2018. The association survey results show that the penetration of Internet users in Indonesia in 2018 rose $10.12 \%$ from a year earlier [2].

Their appearance of today's technology, accompanied by the use of the Internet is rapidly increasing, triggering lawsuits against economic needs. Society becomes increasingly advanced economy accompanied by increased community needs. Economic and technological 
progress are opening opportunities to create jobs. One of the jobs that appear among the community that is in transportation.

2015 was a phenomenal period for the development of transport services. This service becomes one of the jobs for the community. Transport services on demand, or commonly known as the online application-based transportation. History appears this transportation services, initiated by the Uber app that carries Uber taxi as transportation services business based online applications. This was followed by the appearance of Go Car, Grab Car, Grab taxi, and other online-based applications. The emergence of online transportation convenience than as a supporting community, as well as jobs for other people. Now people use the online transport in daily life, so the existence of online transportation is needed to support rapid mobilization demanded [3].

Until the year 2018 has provided approximately 69 brand online transport scattered across Indonesia with the system and has a characteristic that varies. Some of the big names that appear in several cities in Indonesia is Gojek, Grab, Lady-Jek, and Uber. Anwar [4] states that a survey conducted by the Indonesian Consumers Foundation (YKLI) in April 2017, is associated with the presence of public transport-based online rental which is not included in the stretch, showed that Gojek occupy the highest rating of consumer choice $(72.6 \%)$, followed by Grab (66.9\%), then Uber (51\%), and lastly My Blue Bird (4.4\%). Availability of this service cause some users to switch from conventional public transport to transport online. There are many possible reasons for the change, one of which is a factor of the communications or technology sophistication and desire the people who always want convenience [5].

Change from conventional transport models to application-based transportation is very interested in the community and this is a form of social change which requires ease of use modes of transport. The changes that occur in the community is a normal phenomenon. Its influence can spread quickly to other parts of the world thanks to modern communications [6].

Causes and supporting social change such as technology and society itself. The shift of conventional transport services to transport users online influenced by the sophistication of communication tools (technology) and the desire of the people who always want convenience. The behavior of the community in addressing the changes would receive if the change is beneficial (as needed, can be understood and controlled, profitable, not to damage the prestige, improve living standards, do not conflict with the values in the community).

Survey conducted by Yayasan Lembaga Konsumen Indonesia (YKLI) in April 2017 related to the presence of online-based public transport which is not included in the routes, uncovering the reasons put forward by people who choose or use the online transport, namely: cost $(84.1 \%)$, fast $(81.9 \%)$, convenient $(78.8 \%)$, and safe $(61.4 \%)$. It shows that all's cost of service rate ranks first respondent selection [7].

Behind the rapid growth of online transportation today, there are many stories that have sprung from the driver himself. Many cases are cornering the driver of the car online since been blamed for the declining revenues of the conventional transport drivers, in addition to the environmental community cannot accept the presence of cars online. The protest, denial, deterrence and its height were a massive demonstration that rejects the presence of Gojek, Uber and Grab carried by conventional transport driver. Nevertheless, it is not the intention of the driver of the car me bust online to continue to earn a living and to fight for its existence in the social environment in order to be accepted by the community, especially the driver of a conventional car (public transport) one of them in Pekalongan.

In response to emerging dynamics to these problems, the government began to regulate the presence of online transportation on 1 November 2017 to the Minister of Transportation 
Regulation Number 108 Year 2017 on the Implementation of People with Motor Vehicle Equipment General Not in Route. However, the regulation is still causing turmoil. Based on the description of the above background, the researchers are interested in studying the phenomenon of the Public Transportation Mode Transformation case studies in Pekalongan City.

\subsection{Research Gap}

Previous studies that investigated the transport line, has an increased focus on the conflicts that arise between online and conventional transport driver. However, not much research examines the factors unplanned happens so that the conditions of transformation of transportation. Their previous research that focuses on the conflicts that arise, as well as deepened by the transformation from conventional to online transport is expected to will be able to contribute to research, increase knowledge in the study of Public Administration, especially in the field of transformation of an organization and producing win-win conditions between applicators, drivers and passengers in an effort to improve transportation services in Pekalongan City.

\subsection{Research Purpose}

This study aims to analyze and describe controversy of the mode transportation traditional to transportation online in Pekalongan, Indonesia.

\section{Theoretical Framework}

\subsection{Public Service}

According Moenir [8] is an activity performed by a person or group of people with a foundation of material factors through the system, procedures and specific methods in an attempt to meet the interests of others in accordance with their rights. The purpose of public service is to prepare the public services desired or needed by the public, and how states with the right to the public about the options and how to access that provided by the government.

The Constitution Number 25 of 2009 on Public Service classifies three types of services from government agencies and state-owned companies/enterprises [9]. Grouping by type of service is based on the characteristics and nature of activities and services produced products, namely: Administrative services, services of Goods and Services ministry. Based on the three types of the modes of transport based online application included into services.

\subsection{Transformation}

Greenberg and Baron [10] explaining that the changes can be planned change (planned change) or unplanned change (unplanned change), is a planned change is an activity that is intended and deliberate nature and designed to meet some of the organizational goals. Strength in the planned change facing organizations mentioned the following: changes in the products or services, changes in the size and organizational structure, changes in the administrative system, and the introduction of new technologies. Meanwhile, unplanned change or unplanned 
change is a shift in organizational activity for their strength of an external nature, different outside the control of the organization. Unplanned changes occur due to the following: demographic shift workers, the performance gap,

\section{Research Method}

The approach used in this research is descriptive method through literature searches. Data used is secondary data. Data collected by means of a review of the book, literature, records and reports dealing with the problem to be solved [11]. The collected data were analyzed by examining and comparing the literature sources to obtain data that is theoretical.

\section{Result and Discussion}

\subsection{Demographic Shift Workers}

Transport is very important for all of human social life. The simplest form of transportation theoretically is all influenced by human use. Simbolon [12] argues as follows. "In the world there is a saying ... ship transportation follows the trade and trade follow the ship ...", it means that the transport (ship) follow the development of trade and commerce to follow the development of transportation. Thus, the development of a society depends on the development of transport and vice versa. Along with the increasing population in Pekalongan, the public demand for transport will be increasing as well.

Community life today is more dynamic compared to the era before the rapidly developing information technology. A hive of activity as people lack the time to do some work and to meet their daily needs. The most perceived busyness among other timeconsuming in the city package delivery, delivery to the destination that is usually hampered by traffic jams and time-consuming queues when shopping. However, it now can be resolved with a transportation system based online applications in Pekalongan is growing rapidly effective and efficient manner.

The development of the transport network system based online application is able to provide access for the public to meet the needs of goods and services every day, like Grab Send, Go Send, Go Shop, Car Grab, Go Car, and other support tools. Convenience gained by using this online application-based transportation, did not escape the view of entrepreneurs who see opportunity and exploit it. This can increase the absorption of labor and increase social and economic society in the city of Pekalongan.

\subsection{Performance Gaps}

The gap in performance (performance gap) is a gap between what customers and stakeholders expect with what each process and related sub-processes produce in terms of quality, quantity, time, and cost of services and products.

Online presence felt by the public transport is very helpful in supporting the activity. The services provided are also not limited to just take passengers but can also be courier services, food delivery, or shop though. Its ordering process was quite easy. Only rely smartphone connected to the Internet that nowadays most people already have. On one hand with the rise 
of online transport phenomena affect the social envy of conventional public transport. In Pekalongan there is a conflict of transportation riders online and conventional public transport. The existence of online transportation considered to be a competitor of conventional public transport which can reduce their income.

Providing transportation services to the public is the task of the government. Their online transport phenomena that continue to mushroom in Pekalongan and increasingly in demand by the people of this shows the government's inability to provide services to the community. Many of the problems that arise after the transport line, one of which is more congestion. However, in addition to that the convenience provided transportation online makes people feel satisfied and needing transport is considered more convenient online. This shows the gap between the wishes of the people and government performance.

\subsection{Government Regulations}

Government is the organization's power to make regulations and implementing laws and legislation certain region. Governmental functions can be found in the constitution in the form of judicial functions, budget planning, tax, military, and police. Rashid divided the government into four parts, service (public service), construction (development), empowerment (empowering) and setting (regulation) [13].

Transport online appear in the midst of Pekalongan City transportation system that is not well ordered. The government's inability to provide services in the field of public transportation make their opportunities for the private sector that led to this online applicationbased transport and cause social jealousy for conventional transport preexisting, both motorcycles, taxis, buses and so forth. Some large companies are racing to establish an online application-based transport company, such as Gojek, Grab and Uber.

Despite the many problems that arise after the application based transportation, the government is still trying to protect the existence of the service, with the Minister of Transportation issued Regulation Number 118 in 2018 on the implementation of special lease transport [14]. Legal basis for this online-based transportation will provide a good law for the driver transportation online, service providers, and service users. The existence of these regulation scan be interpreted legally recognizes the existence of application-based transport, which in these regulations include tariffs and quotas on the online transport. The government had hoped the regulations that have been made will give the situation, which is a win-win condition between the applicator, the driver, passengers in an effort to improve safety and transportation services in Pekalongan City.

\subsection{Technology Advances}

Technology development has been very rapid indeed. Existing and developing technologies in the era are now so outraged than usual something we find. Through the technology available today we got some benefits, such as we can go somewhere, we want it because lazy to use their own vehicles.

In the era of technological development so far, everything we want to access a particular place can be reached with a very quick time as well as an adequate vehicle. Everyone definitely needs transportation to access a particular place in Pekalongan.

This appliance-based transport be one alternative for the city of Pekalongan, they have a platform that has been studying the social needs of the public transport public (consumers) 
which is connected with the drivers and supported by intelligence Smartphone technology so that they can be tracked using GPS via an application.

Report of the Asosiasi Penyedia Jasa Internet Indonesia (APJII) [1] the population of Indonesia is currently at 246.16 million. Internet users in Indonesia reached 64.8 percent, or about 171.17 million people have been connected to the Internet network throughout 2018 . The association survey results show that the penetration of Internet users in Indonesia in 2018 rose $10.12 \%$ from the previous year. [7] The presence of internet technology facilitates the work of Pekalongan society in many ways not least of travel mobility. The existence of online application-based transportation is also considered by the people of Pekalongan are very helpful in supporting the activity.

\section{Conclusion}

Community life today is more dynamic compared to the era before the rapidly developing information technology. A hive of activity as people lack the time to do some work and to meet their daily needs. Transport is very important for all of human social life. However, it now can be resolved with a transportation system based online applications in Pekalongan is growing rapidly effective and efficient manner.

The presence of online application-based transportation is transportation in accordance with the wishes of the people, which is currently in use transport public life began to shift from a traditional society, modern society and the irrational becomes rational, it shows demographic shift workers (shifting employee demographics) in Pekalongan.

On one hand with the rise of online transport phenomena affect the social envy of conventional public transport. In Pekalongan there is a conflict of transportation riders online and conventional public transport. The existence of online transportation considered to be a competitor of conventional public transport which can lower their income, it disparities performance (performance gaps).

Despite the many problems that arise after the application based transportation, the government is still trying to protect the existence of these services, publishing Government regulations (government regulation), Regulation of the Minister of Transportation Number 118 in 2018 on the implementation of special lease transport [14]. Regulations that have been made later can provide situations, win-win conditions between applicators, drivers and passengers in an effort to improve safety and transportation services in Pekalongan City

The development of innovation in technology (advances in technology) must also be balanced with regulation. Existing and developing technologies in the millennial era are now so outraged than usual something we find. Through the technology available today many benefits for Pekalongan City community to support the activities, such as people who lived in the area that are hard to reach by conventional transport can take advantage of changes in technology today.

\section{References}

[1] A. S. R. (Association of I. Internet), "Penetration \& Profile User Behavior Internet Indonesia."

[2] A. S. Wardani, "Jumlah Pengguna Internet di Indonesia Sentuh Angka 171 Juta," Liputan 6, 2019 . .

[3] N. Muharany, "Transformasi Sistem Transportasi Publik (Studi Pada Penyelenggaraan 
Angkutan Sewa Khusus Berbasis Aplikasi)," 2018.

[4] A. A. Anwar, "Online vs konvensional: keunggulan dan konflik antar moda transportasi di kota makassar," ETNOSIA J. Etnogr. Indones., vol. 2, no. 2, pp. 220-246, 2017.

[5] B. J. Oktaviani, R, "Perception Against the Use of Public Transportation in Bandung," $J$. Transp., pp. 153-160, 2018.

[6] Soekanto, Role of Sociology An Introduction. Jakarta: PT. Rajawali Press, 2009.

[7] YLKI, "Warta Konsumen : Transportasi Online; Kawan atau Lawan.".

[8] H. A. S. Moenir, "Pelayanan Umum di Indonesia," Cetakan kelima, PT Bumi Aksara, Jakarta, 2001.

[9] "The Constitution Number 25 of 2009 on Public Service."

[10] Wibowo, Change management. Jakarta: King Grafindo Persada, 2011.

[11] T. A. Nazir, A. M. Jacobs, and J. K. O'Regan, "Letter legibility and visual word recognition," Mem. Cognit., vol. 26, no. 4, pp. 810-821, 1998.

[12] M. M. Simbolon, “Ekonomi Transportasi,” Jakarta Ghalia Indones., 2003.

[13] M. Labolo, Memahami Ilmu Pemerintahan. Rajawali Pers, 2008.

[14] "Regulation of the Minister of Transportation No. 1182018 Transport on the Implementation of Special Leases." 